\title{
PENGEMBANGAN LKPD APLIKATIF INTEGRATIF BERBASIS INQUIRI TERBIMBING PADA MATERI KESETIMBANGAN KIMIA
}

\section{DEVELOPMENT OF APLICATIVE INTEGRATIVE STUDENT WORKSHEET BASED ON GUIDED INQUIRY ON EQUILIBRIUM CHEMICAL SUBJECT}

\author{
Yendro Try Satura*, Abdullah, dan Radjawali Usman Rery \\ ${ }^{1}$ Program Studi Pendidikan Kimia FKIP Universitas Riau, Pekanbaru, Indonesia \\ *Email: Yendro.trysatura @student.unri.ac.id
}

Diterima: 18 Januari2020. Disetujui: 21 Januari 2020. Dipublikasikan: 9 Januari2021

\begin{abstract}
Abstrak: Penelitian ini bertujuan untuk mendesain Lembar Kegiatan Peserta Didik (LKPD) yang aplikatif integratif berbasis inquiri terbimbing pada materi kesetimbangan kimia untuk kelas XI SMA /MA sederajat. LKPD ini membantu peserta didik mengaitkan materi dengan fenomena alam ataupun kehidupan sehari hari dengan basis inquiri terbimbing. Penelitian ini dilakukan di SMA N 4 Pekanbaru dan SMA N 15 Pekanbaru. Sebelum diujikan kesekolah LKPD di dinilai kelayakan oleh tim validator. Kelayakan LKPD diujikan pada validator dengan intrument kelayakan yang sudah dirancang. Metodologi penelitian yang digunakan pendekatan ADDIE (Analyze, Design, Development, Implementation, Evaluation). Tahap penelitian ini adalah tahap pengga lian potensi $\mathrm{m}$ a sa la $\mathrm{h}$ dan perancangan. Skor rata rata validator menunjukkan hasil $93.5 \%$ yang berarti layak digunakan. Uji respon guru didapatkan hasil skor rata rata $89.5 \%$ dan uji respon peserta didik skor rata rata $90.25 \%$ yang berarti LKPD dapat digunakan dalam pembelajaran.
\end{abstract}

Kata Kunci: Pengembangan, aplikative integratif, inquiri terbimbing

\begin{abstract}
The aimed This research to design aplicative integrative student worksheet based on guided inquiry on equilibrium chemical subject for XI class senior high school. Student worksheet helping to connect material with natural phenomena or daily life on guided inquiry base. This reasearch was conducted in the state high school pekanbaru and state high school 15 peka nbaru. Worksheet before being tested for eligibility by validator team. The feasibility of the worksheet is tested with the feasibility instrument has been designed. The research methodology used by the ADDIE (Analyze, Design, Development, Implementation, Evaluation). This research stage is of extracting potential problem and design. Student worksheet which was validated by validator showed a $93,5 \%$ result, which meant that it was worth using. Teacher response $89,5 \%$ an student response $90,25 \%$ test which meant can be used in learning.
\end{abstract}

Keywords: Development, aplicative integrative, guided inquiry

\section{PENDAHULUAN}

Pembelajaran adalah proses interaksi antara pendidik, peserta didik dan sumber belajar pada suaatu lingkumngan belajar [8]. Pendekatan pembelajaran yang harus dikembangkan pendekatan saintifik meliputi mengamati, menanya, mencoba, mengolah data, menyimpulkan. Dalam pembelajaran juga dapat digunakan model yang memperkuat terterapnya pendekatan saintifik salah satunya inquiri tebimbing.

Inquiri terbimbing adalah model pembelajaran dengan kegiatan inquiri dimana masalah dikemukakan oleh guru atau sumber belajar kemudian peserta didik bekerja untuk menemukan jawaban terhaap masalah dibawah bimbingan guru. Langkah langkah pembelajaran menggunakan model inquiri adalah merumuskan masalah,menyusun hipotesis,mengumpulkan data, membuktikan hipotesis dan menyimpulkan. Model pembelajaran inquiri [5].

Kimia merupakan cabang ilmu yang berfokus pada bagaimana peseta didik mengkronstruksi pengetahuan yang dimilikinya. Pemahaman terhadap suatu konsep kimia tidaklah cukup apabila hanya berasal dari guru, tetapi peserta didik juga harus bisa mengkontruksi pengetahuannya sendiri. Menurut teori konstrutivisme guru tidak hanya sekedar memberikan pengetahuan pada peerta didik, akan tetapi mereka harus membangun sendiri pengetahuannya. Peserta didik dapat membangun pengetahuan sendiri melalui rangsangan guru ataupun bahan ajar. Bahan ajar dapat digunakan salah satunya LKPD.

LKPD merupakan suatu bahan ajar cetak yang berupa lembar lembar kertas yang berisi petunjuk pelaksana an tugas yang harus dikerjakan baik secara teoritis maupun praktis oleh peserta didik. LKPD berfungsi sebagai bahan ajar yang meminimalkan peran guru dan mengatifkan Peserta didik.

Berdasarkan hasil wawancara dengan guru SMA N 4 Pekanbaru dan SMA N 15 Pekanbaru menyatakan bahwa LKPD yang diberikan guru berasal dari penerbit tertentu, yang mana LKPD tersebut kurang membangun minat peserta didk untuk mendapatkan pengetahuannya sendiri. LKPD sebaiknya dirancang sendiri oleh guru karna guru lebih mengetahui kondisi peserta didik dan kurikulum digunakan disekolah. Hal ini dilakukan 
agar LKPD digunakan sesuai karakter peserta didk dan kurikulum yang digunakan. Salah satu LKPD yang dapat digunakan adalah LKPD aplikatif integratif. LKPD aplikatif integratif yaitu lembar kerja peserta didik yang membantu peserta didik untuk menerapkan atau mengintegrasikan kedalam kehidupan sehari hari. LKPD aplikatif interatif dipaduakan dengan inquiri terbimbing dapat membantu peserta didik menemukan konsep sendiri. LKPD aplikatif integratif didasarkan pada pendekatan kontekstual yang mana mengaitkan materi belar kedalam kehidupan sehari hari. Prisip dasar pendekatan kontekstual a da lah konstruktivisme dan inquiri. Prnsip konstruktivisme adalah membangun pengatuan sendiri dengan konteks terbatas. Bahan ajar menekankan menemukan sendiri konsep dan pembelajaran bermakna.

Penelitian relevan terkait judul pengembangan LKPD aplikatif integratif berbasis pendekatan saintifik pada materi laju reaksi penelitian dilakuka n siti mutmainah dkk, (2018) dengan kelayakan 97,5\% (valid). Penelitian relevan terkait pengembangan LKPD berbasis inquiri terbimbing pada mater kesetimbangan kimia dengan kelayakan LKPD 84,72 (valid).

Berdasarkan penelitian yang relevan maka penulis melakukan penelitian pengembangan LKPD aplikatif integratif pada materikesetimbangan kimia untuk kelas XI sma/ma sederajat

\section{METODE PENELITIAN}

Metode penelitian yang digunakan peneliti dalam membuat LKPD aplikatif integratif berbasis inquiri terbimbing menggunakan metode Research and development (R\&D) melaui pendekatan ADDIE (Analyze, Design, Development, Implementation, Evaluation) [10]. Pengembangan ini tahap pertamanya adalah menggali potensi dan masalah yang ada pada objek yang diteliti.Kemudian membuat rancangan LKPD yang sesuai kebutuhan, LKPD divalidasi oleh tim ahli materi. LKPD yang divalidasi direvisi hingga dintakan valid oleh validator. Setelah LKPD dinyatakan valid, dilakukan uji coba satu satu dan respon pengguna guna melih a respon guru dan peserta didik terhadap LKPD yang dikembangkan.

\section{HASIL DAN PEMBAHASAN}

Produk yang dihasilkan berupa LKPD aplikatif integratif berbasis inquiri terbimbing pada materi kesetimbangan kimia untuk kelas XI sma/ma sederajat.

Tahap penelitian LKPD ini melalui tahapan ADDIE (Analyze, Design, Develpment, Implementation, Evaluation)

(a) Analyze (analisis)
Pada tahap ini dilakukan analisis kebutuhan, analisis materi, dan analisis karakter peserta didik Hal ini dilakukan guna menetapkan isian LKPD yang sesuai dengan materi, kebutuhan sekolah dan karakter peserta didik.

(b) Design (Perancangan)

Dilakukan perancangan awal untuk menentukan isi LKPD yang sesuai dengan materi, kurikulum dan karakter dari peserta didik. Adapun rancangan awal berupa perumusan KD,judul LKPD, Tujuan, Indikator, dan kegiatan LKPD yang sesuai sintaks inquiri terbimbing.

(c) Development (Pengembangan)

LKPD yang sudah dirancang divalidasi oleh validator / tim ahli materi. LKPD dinilai berdasarkan instrument yang telah dibuat. LKPD dinilai berdasarkan 6 aspek yang diantaranya aspek kelayakan isi, aspek kelayakan bahasa, aspek kelayakan inquiri terbimbing, aspek aplikatif integratif, aspek penyajian dan aspek kegrafisan. Hasil pada tahap ini dilakukan pengujian produk LKPD oleh tim ahli menggunakan lembar validasi yang dibuat. Pada tahap ini dilakukan evaluasi formatif untuk merevisi produk instruksional dan proses yang telah dilakukan sebelum implementasi. Adapaun hasil validasi yang didapat.

Dari grafik dapat dilihat bahwa LKPD yang divalidasi oleh validator layak digunakan. Setelah dilakukan validasi dilakukan uji satu satu dan uji respon pengguna. Berdasarkan uji respon guru didapatkan hasil $89.5 \%$ yang dinyatakan sangat tinggi. Dan uji respon peserta didik $90.25 \%$ yang dinyatakan sangat tinggi. Dari hasil validasi dan uji respon pengguna dapat dinyatakan bahwa LKPD layak digunakan dalam pembelajaran.

Dengan penerapan hasil pengembangan LKPD berbasis inkuiri dapat menunjang pembelajaran secara interaktif dan mendorong siswa lebih bekerja keras dalam menyelesaikan permasalahan yang diberikan. Permasalahan mmebutuhkan solusi sehingga siswa akan lebih berpikir abagaiman menyelesaikannya. Kemampuan berpikir kritis siswa sangat panting untuk membant menyelesaikan masalah. Inkuiri terbimbing membantu siswa dalam bekerja.LKPD yang valid dan layak memberiarahan pada siswa dalam bekerja. Tentu siswa lebih terbantu dalam bekerja dengan model inkuiri terbimbing. Dimana langkah dan tujuan permasalahan sudah ditentukan guru dalam LKPD yang dikembangkan. Dengan dekimia, LKPD dapat membantu guru dalam mensukseskan program pemerintah dalam memajukan dan mencapai pendidikan nasional [1719]. 


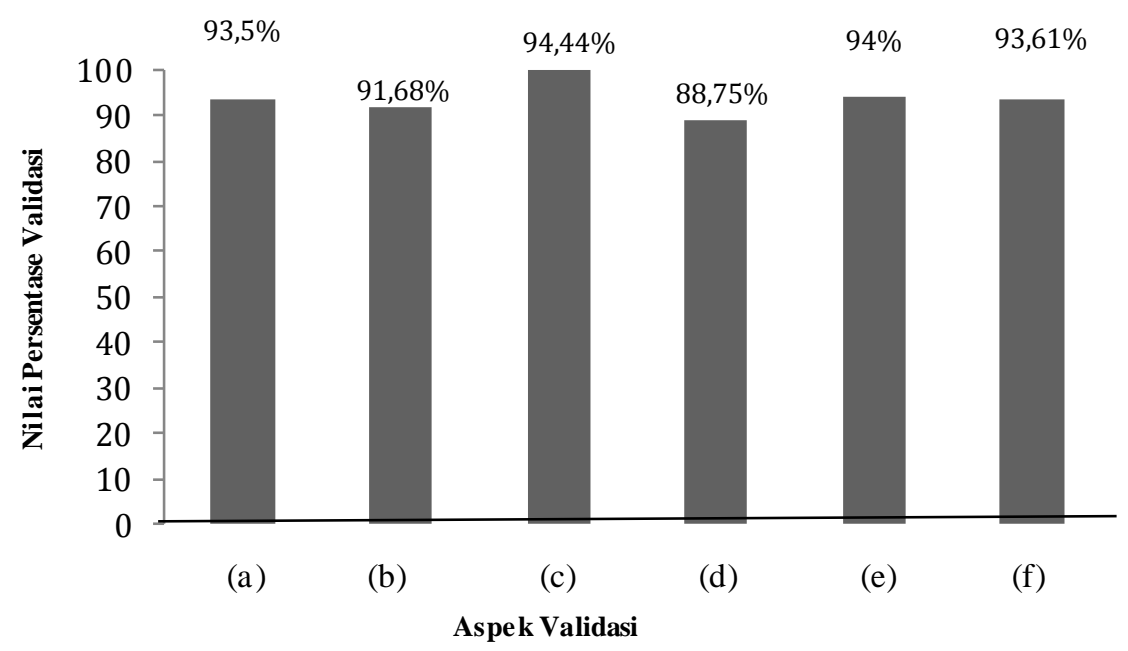

Gambar 1. Skor Rata-Rata Penilaian Validasi LKPD

Kelayakan Aspek Isi, (b) Kelayakan Aspek Bahasa, (c) Kelayakan Aspek Kelayakan inquiri terbimbing, (d) Kelayakan Aspek Kelayakan aplikatif integratif, (e) Kelayakan penyajian,(f) aspek kelayakan kegrafisan.

\section{KESIMPULAN}

LKPD aplikatif integratif berbasis inquiri terbimbing pada materi kesetimbangan kimia untuk kelas XI SMA/MA sederajat telah memenuhi 6 a spek kelayakan dengan persentase $93.6 \%$ sehingga LKPD dapat dinyatakan valid. Uji coba terbatas dilakukan kepada guru dan peserta didik (uji coba satu satu dan kelompok kecil) diperoleh hasil respon pengguna berada kriteria baik dengan persentase rata rata 89.5 $\%$ sebesar oleh guru dan $88 \%$ oleh peserta didik sehingga LKPD dapat dikatakan layak digunakan dalam pembelajaran

\section{DAFTAR RUJUKAN}

[1] Prastowo, A. (2011). Panduan kreatif membuat bahan ajar inovatif.

[2] Prastowo, A. (2014). Pengembangan bahan ajar tematik. Pedadogya: Yogyakarta

[3] Sitepu, B. P. (2014). Pengembangan sumber belajar. PT Raja Grafindo Persada: Jakarta

[4] Al-Fialistyani, D., Andayani, Y., Hakim, A., \& Anwar, Y. A. S. (2020). Literasi Kimia Pada Aspek Kompotensi Melalui Pembelajaran Inkuiri Terbimbing Dengan Pendekatan Etnosains. Jurnal Pijar Mipa, 15(5), 537-540.

[5] Daryanto. (2014). Pendekatan Pembalajaran Saintifik kurikulum 2013. Gava Media: Yogyakarta

[6] Dimyati dan Mudjiono. (2002). Belajar dan Pembelajaran. Rineka Cipta: Jakarta

[7] Nasional, K. P. (2010). Panduan Pengembangan Bahan Ajar Berbasis TIK. Jakarta. Direktorat Pembinaan SMA.

[8] Astariana, W., Syafi'i, W., \& Sayuti, I. (2016). Pengembangan Lembar Kerja Siswa (LKS) pada Materi Sistem Pencernaan Kelas VIII SMP dengan Pendekatan
Saintifik (Doctoral dissertation, Riau University).

[9] Hamalik, O. (2007). Proses Belajar Mengajar. Bumi Aksara: Jakarta

[10] Permatasari, I., Ramdani, A., \& Syukur, A. (2019). Pengembangan Bahan Ajar IPA Berbasis Inkuiri Terintegrasi Sets (Science, Environment, Technology And Society) pada Materi Sistem Reproduksi Manusia. Jurnal Pijar Mipa, 14(2), 74-78.

[11] Mutmainah, S., \& Nurhadi, M. (2018). Pengembangan Lembar Kerja Peserta Didik Yangaplikatif-Integratif Berbasis Pendekatan Saintifik Development of ApplicativeIntegrative Student Worksheet Based on Scientific Approach on Reaction Rate Subject. Jurnal Kimia Dan Pendidikan Kimia UNS, 3(1), 6-12.

[12] Widowati, A., \& Anjarsari, P. (2013). Pengembangan Integrated Science Worksheet Berbasis Guided Inquiry Learning dalam Rangka Menyongsong Kurikulum 2013. Jurnal Pendidikan Matematika dan Sains, 1(2), 165 175.

[13] Sugiyono, S. (2010). Metode penelitian kuantitatif dan kualitatif dan R\&D.

[14] Slameto. (1988). Belajar dan Faktor-faktor yang Mempengaruhinya. Bina Aksara.

[15] Trianto, M. P. (2009). Mendesain model pembelajaran inovatif-progresif. Jakarta: Kencana.

[16] Usman, S., Qodir, Z., \& Hasse, J. (2014). Radikalisme Agama di Indonesia. Yogyakarta: Pustaka Pelajar.

[17] Ilham, I., Jufri, A. W., \& Lestari, N. (2020). Pengembangan Lembar Kerja Peserta Didik Model Inkuiri Berbantuan Multimedia Pada 
J. Pijar MIPA, Vol. 16 No.1, Januari 2021: 64-67

Materi Perubahan Lingkungan. Jurnal Pijar Mipa, 15(5), 514-519.

[18] Al-Fialistyani, D., Andayani, Y., Hakim, A., \& Anwar, Y. A. S. (2020). Literasi Kimia Pada Aspek Kompotensi Melalui Pembelajaran Inkuiri Terbimbing Dengan Pendekatan Etnosains. Jurnal Pijar Mipa, 15(5), 537-540.

[19] Yasmin, N., Ramdani, A., \& Azizah, A. (2015). Pengaruh metode inkuiri terbimbing terhadap keterampilan proses sains dan hasil belajar biologi siswa kelas VIII di SMPN 3 Gunungsari tahun ajaran 2013/2014. Jurnal pijar MIPA, 10(2). 